natural to pay special attention to this aspect of the international refugee policy. Leonard Dinnerstein's research in particular has provided us with a fairly comprehensive picture of the activities of interest groups, lobbyists and members of Congress in connection with the struggle over the Displaced Person's Act of 1948 and its amendment in 1950 . However, less is known about the Executive branch and the refugee policy controversies. Leif Eliasson is focusing his study on this aspect, with the emphasis on the first two postwar years. It is possible that a special study will take up also USEP, United States Escapee Program, which is one of the most clear-cut instances where a refugee program has been initiated as a means to a purely political end.

The individual studies within the project may at first glance seem rather disparate. However, taken together they are intended to illuminate different facets of the same problem, and they are also, in fact, chosen according to a comprehensive plan. The guiding principle has been, as I said, to look at the refugee policy problems in the context of international politics and relations. However, the individual studies have been organized not only with this principle in mind, but also in order to constitute studies with their focus on different levels. Firstly, the International level, with the international organizations, UN, IGCR, UNRRA, IRO, UNHCR, The International Red Cross. Secondly, the National level, represented by the United States, Great Britain, Germany and Sweden. Thirdly, the Regional level, represented by the British occupation zone in Germany. A study on the local and individual level may also be undertaken. It goes without saying that no study deals with one level exclusively.

If we, on the other hand, look at the actors, we will find that the individual studies are organized so that they deal with different categories. To some extent these categories correspond to the different levels I mentioned. But in addition to governments, non-governmental organizations and agencies, and voluntary organizations there are also studies focusing on refugees as actors, namely, the German Heimatvertriebenen and Ostflüchtlinge as well as Jewish infiltrees.

Göran Rystad is the Director of the "Uprooted by the War: Refugees, Displaced Persons and Expellees in Europe in the Early Post-War Era" project at the University of Lund, Sweden.

\title{
"The Refugee Crisis: British and Canadian Responses" International Symposium Report
}

\author{
by C. Michael Lanphier and Noreen Spencer-Nimmons
}

January 4-7, 1989 marked the third international symposium to be co-sponsored by the Refugee Studies Programme at the University of Oxford, and the Centre for Refugee Studies (formerly the Refugee Documentation Project) at York University, Canada. The symposium title reflects the framework for British participants to address current refugees issues from the perspective of Britain's Race Relations Act, and Canadians from the perspective of the recent Multicultural Act.

\section{Purpose}

The purpose of the symposium was to share expertise with those working directly in the field of refugee research, policy-making and social service programmes. More than 300 people had preregistered for the symposium by the opening day. This number is probably attributable to the publicity on the part of the Oxford Refugee Studies Programme. Numbers escalated as word spread that the symposium was a concerted effort to bring government representatives, academics, practitioners and refugees together to share ongoing research work and to re-examine perspectives on solutions to the refugee crisis.

\section{Participation}

The Canadian team of 31 participants provided representation from ten universities (from British Columbia to Newfoundland), the Ontario and the Quebec Provincial Governments, three
Canadian press outlets, three law firms and six non-governmental service delivery organizations. The Canadian High Commissioner, Donald S. McDonald, hosted the Symposium reception on January 6th and attended dinner that evening at Keble College with the cosponsors and conference participants. The Canadian High Commissioner's staff at Canada House London, provided resource support throughout the preparation of the symposium. Michael Hellyer, Chief Education Officer, was especially invaluable as chairman of the joint organizing committees, acting throughout the fourteen month preparation period as a liaison resource between the British and Canadian co-ordinators.

Refugees from at least eleven different countries currently residing in the UK or Canada, also participated in the overall programme. Included were two students co-sponsored by York University and World University Services Canada and a recent participant in the Centre for Refugee Studies co-sponsored Refugee Women in Canada Workshop Weekend.

The UK participation included representatives from 45 NGOs, nineteen academic institutions, three government departments, eight media outlets and six local governments. Other international participation came from seven international voluntary agencies (including the UNHCR, the Red Cross, Amnesty International), eight other governments (Denmark, Norway, Sweden, Finland, the Netherlands, Japan, Ethiopia, the European Community) and three academic institutions. 


\section{Opening Day}

The Opening Day Ceremony was held at Rhodes House, University of Oxford. The keynote address, "The Nature of the Crisis" was delivered by Zia Rizvi, Secretary General, Independent Commission on International Humanitarian Issues. Dr. Rizvi emphasized the necessity for resolutions to the global refugee crisis to be based exclusively upon co-operative and universal humanitarian efforts. Later, Timothy Renton, Minister of State, Home Office, presented a keynote address on behalf of the U.K.

As Minister for Multiculturalism and Citizenship Gerry Weiner declined to attend, no Canadian counterpart from the Federal Government of Canada was present for the keynote addresses. Likewise, Gordon Fairweather, chair of Canada's newly formed Immigration and Refugee Board was called to remain in Canada. Reading Mr. Fairweather's speech on his behalf was Stanley Knight, the British Columbia assistant deputy of that Board.

Murad Velshi, MPP, parliamentary speaker, delivered the keynote address on behalf of the Minister of Citizenship, Ontario Province. Mr. Velshi, together with Clive Joakim, Director of Ontario's Citizenship Development Branch, participated fully throughout the symposium and contributed their expertise in some "Issues of Resettlement" sessions.

\section{Programme}

The programme was divided into three major divisions, the presentation of papers, the refugee experience,, and parallel sessions on resettlement. Some categories discussed were "Refugees: The Responsibility of Government"; "The Letter: Current Legislation"; "The Spirit: Historical and Social Perspectives"; "Psycho-social Issues of Resettlement"; and "The Context of Resettlement". The category "The Refugee Experience" involved personal accounts from refugees in the UK.

In a special presentation by the Chair of the recent Canadian Task Force Commission on Mental Health, Visible Minorities and Refugees, Morton Beiser reported that overall some 30 per cent of refugees suffer from some combination of physical and mental health problems, although the use of the health care system

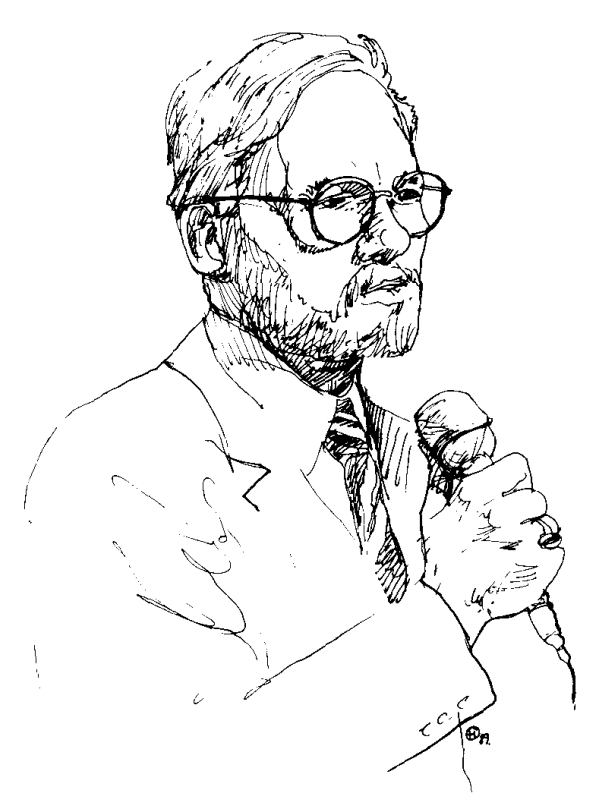

\section{Michael Lanphier}

by refugees in Canada is no greater than by other Canadians. Yet refugees have experienced particular forms of stress which often represent considerable personal loss from their pre-emigration situation. The Canadian health care system is presently inadequate for providing effective health care delivery: greater staff multicultural training and greater outreach are prominent necessary improvements. Peter Cumming, Chair of the Task Force Commission on Access to Trades and Professions, reported on some of his own work in this field, the purpose and organization of the Task Force. Unfortunately, because the Canadian government still has not released either Task Force Report, both Dr. Beiser and Prof. Cumming were unable to give the important details of the findings which had been anticipated by representatives from other governments and symposium participants.

\section{Summary}

Canadian participants addressed the agenda topics within the context of Canada's Multicultural Act. The British participants addressed the agenda topics from within the context of Britain's Race Relations Policy. Mr. Weller's address, for example, presented the British equivalent of multiculturalism, known in England as "liberal nationalism". Discussion from the audience reflected concern over the deteriorating situation for claimants in Britain. Similar concerns focused on Canada's recent passing of Bills C-55 and C-84 and, in general, the closing of doors to refugees throughout the Western world.

In addition, great concern was expressed about insensitivity to the life plans of refugees themselves and the abrupt fracture of refugee families. Good will among the NGOs and refugee workers was evident. Representatives gave full support to recommendations such as the adoption in Britain of Canada's private sponsorship programme, the reduction of intake bias with respect to refugees from Africa, the Middle East and Sri Lanka, and the acceptance of asylum applications from outside the UK; in Canada, the relaxation of the definition of Designated Class and that Family Reunification be allowed for refugee claimants in exceptional circumstances.

More than 300 participants applauded efforts to encourage a refocusing of refugees from victim to resource, and to work toward durable solutions for refugees, not simply permanent solutions to immigration issues in all receiving countries.

\section{Closing Ceremony and the Way Forward}

The symposium was officially closed following the presentation of recommendations from a representative from each of the "Issues of Resettlement" sessions. At press time, these recommendations were being collated and prepared at the Refugee Studies Programme, University of Oxford for formal presentation to the Centre for Refugee Studies. Closing presentations were given by Marlinda Freire (Chief Psychiatrist, Toronto Board of Education), Philip Rudge (European Council for Refugees and Exiles) and Michael Lanphier (Centre for Refugee Studies). Each speaker synthesized the events of the symposium in light of the global refugee crisis and approached the "Way Forward" as a task of great magnitude requiring international cooperation, research, and the application of progressive, global humanitarianism.

C. Michael Lanphier and Noreen Spencer-Nimmons were the Canadian coordinators of the symposium. 